\title{
The 3550 year BP-1944 A.D. magma-plumbing system of Somma-Vesuvius: constraints on its behaviour and present state through a review of $\mathrm{Sr}-\mathrm{Nd}$ isotope data
}

\author{
Lucia Pappalardo, Monica Piochi and Giuseppe Mastrolorenzo \\ Osservatorio Vesuviano, Istituto Nazionale di Geofisica e Vulcanologia, Napoli, Italy
}

\begin{abstract}
Vesuvius, dominating the densely-populated Neapolitan area, is one of the most dangerous volcanoes in the World. Its destructive power derives from energetic subplinian and plinian eruptions, such as the one which occurred in 79 A.D. Generally such large-scale events follow a long period of quiescence; a behaviour interpreted as the gradual build-up of magma volumes between periods of major activity. After the 1631 subplinian eruption until the last 1944 A.D. eruption, it experienced an almost continuous and less energetic explosive/effusive activity. The erupted magmas are characterized by undersaturated potassic to ultrapotassic nature, and compositional and Sr-isotopic variability. Furthermore geobarometric studies indicate two different crystallization depths located at 4 and $>11 \mathrm{~km}$, respectively. According to most of the recent literature, the eruptions were triggered by the injection in a shallower magma chamber, of isotopically distinct magma batches derived from heterogeneous mantle source(s) and/or contamination processes occurred within the deep reservoir. In our review of petrochemical data, we consider the period between the 3550 years BP plinian eruption and the 472 A.D. sub-plinian eruption, which includes 79 A.D. event, and the most recent period of activity which started in 1631 A.D. and lasted up to the 1944 A.D. eruption, characterized by a near continuous effusive/explosive activity. For both periods we identify a correlation between Sr-isotopical features of magmas and their crystallization depth. In particular, we show that pyroxenes have Sr-isotopic ratios lower than 0.7074 and an equilibrium crystallization depth of 22-11 km. Moreover feldspars have higher ${ }^{87} \mathrm{Sr} /{ }^{86} \mathrm{Sr}$ values $(0.7075-7)$ and an equilibrium crystallization depth of about $4 \mathrm{~km}$. Therefore the most radiogenic magmas did not derive from a deeper reservoir but their higher Sr-isotopic ratios have been acquired at a shallower depth likely by crustal contamination during magma evolution. In contrast, the lower Sr-isotope compositions characterise the less contaminated magmas coming from deeper crustal levels. On the basis of this evidence, the temporal Sr-isotopical variation of magma which erupted in the 1631-1944 A.D. period probably derives from the progressive withdrawal of the shallow magma chamber, which was completely empty before the 1805-1944 A.D. period of volcanism. Therefore the effusive and explosive events of the most recent 1805-1944 A.D. period were fed directly by the deep reservoir located at a depth exceding $11 \mathrm{~km}$.
\end{abstract}

Key words Somma-Vesuvius - magma chambercrustal contamination

Mailing address: Dr. Lucia, Pappalardo, Osservatorio Vesuviano, Istituto Nazionale di Geofisica e Vulcanologia, Via Diocleziano 328, 80124 Napoli, Italy; e-mail: lucy@ov.ingv.it

\section{Introduction}

Vesuvius is one of the most dangerous volcanoes in the world. At the present, half a million people live in a near-continuous belt of towns and villages around the area possibly exposed to the effects of future eruptions. Due to the high volcanic risk, Vesuvius is among the 
best- studied and monitored active volcanoes. Much research (e.g., Santacroce, 1987; Civetta et al., 1991; Civetta and Santacroce, 1992; Mastrolorenzo et al., 1993; Rolandi et al., 1993, 1998; Santacroce et al., 1993; Marianelli et al., 1995, 1999; Cioni et al., 1995, 1998; Arrighi et al., 2001; Peccerillo, 2001; Somma et al., 2001; Andronico and Cioni, 2002) has been devoted to reconstructing its volcanic and magmatic history with the aim of understanding the proceeding of geochemical and geophysical precursors and forecasting its future behaviour.

In spite of the wealth of studies, many problems related to magma genesis and evolution and to the present state of the Vesuvius plumbing system remain open: i) the intraplate versus subduction-related origin of potassic magmatism (e.g., Beccaluva et al., 1991; Ayuso et al., 1998; Peccerillo, 2001); ii) the relative roles of source composition and low-pressure processes in determining the geochemical features of volcanic products (e.g., Savelli, 1967, 1968; Turi and Taylor, 1976; Cortini and Hermes, 1981; Civetta et al., 1991; Civetta and Santacroce, 1992; Santacroce et al., 1993; Cioni et al., 1995; Fulignati et al., 1995; Ayuso et al., 1998; Fulignati et al., 1998; Del Moro et al., 2001; Gilg et al., 2001; Somma et al., 2001); and iii) the present state of the plumbing system, constituted or not by a shallower magma chamber (e.g., Santacroce, 1987; Zollo et al., 1996; De Natale et al., 2001).

In this paper, petrological data are revisited to investigate the role of low-pressure evolutionary processes in magma genesis and their relationships with the style of eruptions (moderate explosive/effusive or highly explosive) during the 3550 years BP-1944 A.D. period of activity for which a complete set of data have been collected.

\section{Geological and petrological background}

Somma-Vesuvius (fig. 1a-c) is a strato-volcano consisting of a recent cone, the Vesuvius, which rises within the older Somma caldera and build ups on the Meso- and Cenozoic carbonatic succession cropping out in the nearest Apennine. The age of volcanic rocks ranges between not less than $300 \mathrm{ka}$ (Brocchini et al., 2001 and ref- erences therein) and 1944 A.D. At present, Vesuvius is in a quiescent state characterised by fumarolic and low-magnitude seismic activities.

Somma-Vesuvius has been characterized by both highly explosive subplinian and plinian eruptions, as well as intermediate and small scale explosive and explosive/effusive ones. The plinian eruptions, such as the well-known 79 A.D. event, were preceded by long periods of quiescence; a behaviour interpreted as the gradual build-up of the magma reservoir between periods of major activity (e.g., Civetta $e t$ al., 1991; Civetta and Santacroce, 1992 and references therein; Mastrolorenzo et al., 2002). A ca. 300 years long period of continuous moderately explosive and effusive eruptions followed the 1631 A.D. subplinian event. However a quite moderate explosive activity can also be inferred for the periods between 79 A.D. and 1631 A.D. (Medioeval eruptions, Rolandi et al., 1998; Somma et al., 2001) and between the 79 A.D. and 472 A.D. (Ancient historic eruptions, Rolandi et al., 1998; Somma et al., 2001).

A $300 \mathrm{~km}^{3}$ magma volume is inferred to have been erupted throughout the history of Somma-Vesuvius (Civetta and Santacroce, 1992). One to a few $\mathrm{km}^{3} \mathrm{DRE}$ of magmas are generally erupted during sub-plinian and plinian eruptions (e.g., Santacroce, 1987; Civetta and Santacroce, 1992; Rolandi et al., 1993), while 0.01 to $0.1 \mathrm{~km}^{3}$ DRE of magmas are erupted during intermediate and small scale events characterizing the last 300 years (Scandone et al., 1986; Mastrolorenzo et al., 1993; Arrighi et al., 2001). A near constant averaged output rate of about $0.3 \mathrm{~m}^{3} / \mathrm{s}$ has been calculated for the whole volcano history (Scandone et al., 1986; Civetta and Santacroce, 1992).

The magmatic system of Somma-Vesuvius produced silica undersaturated potassic (KS) to ultrapotassic (HKS) rocks and consisted of multidepth reservoirs located at about 4 and $10 \mathrm{~km}$ as deduced by fluid and glass inclusion data (e.g., Belkin et al., 1985, 1998; Cortini et al., 1985; Belkin and De Vivo, 1993; Cioni et al., 1998; Marianelli et al., 1999; Cioni, 2000). K-basalts to $\mathrm{K}$-trachytes were produced in the oldest period of volcanism, before 11500 years BP. Between 11.5 ka BP and 79 A.D., the eruptions produced Kphonolitic tephrites to K-phonolites. Finally, be- 


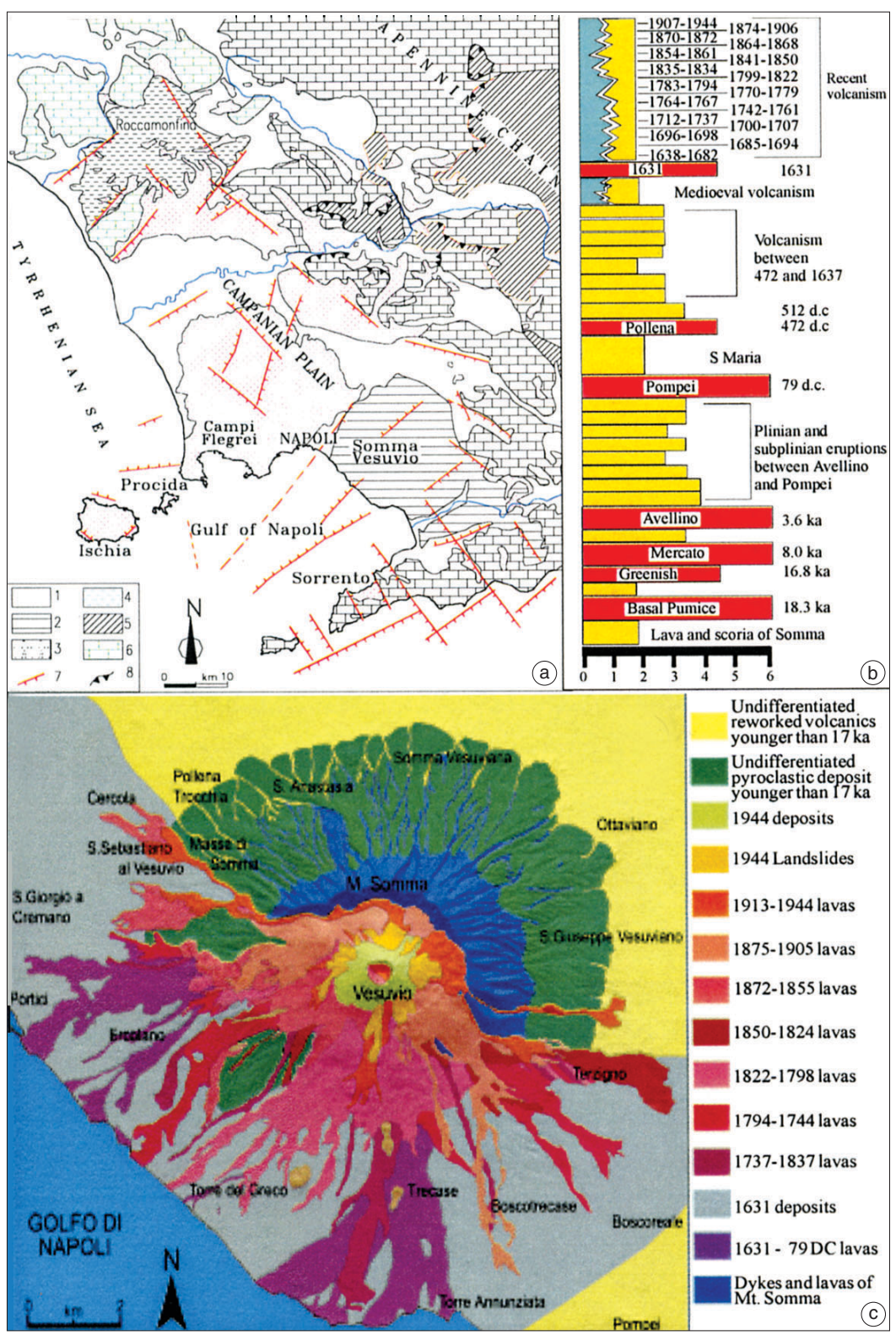

Fig. 1a-c. Somma-Vesuvio map showing: a) Geological sketch map of Campanian Plain $1=$ Quaternary and active terrigenous sediments; 2 = Somma-Vesuvius volcanic rocks; $3=$ Phlegraean volcanic rocks; $4=$ Roccamonfina volcanic rocks; $5=$ Pliocene and Miocene terrigenous sediments; $6=$ Mesozoic carbonatic units; $7=$ Faults; $8=$ nappes. b) Reconstructed Somma-Vesuvius stratigraphic succession, modified after Santacroce (1987) on the basis of data from Rolandi et al. (1993, 1998) and Somma et al. (2001), red = high-energetic eruptions, yellow = moderate/low explosive eruptions, green $=$ effusive eruptions, $x$-scale indicates the erupted volume. c) Geological sketch map of Somma-Vesuvius, after Santacroce (1987). 
tween 472 A.D. and 1944 A.D., leucitic tephrites to leucitic phonolites were erupted. The crystallinity of Somma-Vesuvius volcanic rocks is strongly variable, from nearly aphiric (mostly in the plinian eruptions) to highly porphiritic (in 472 A.D. eruption and in the products younger than 1631 A.D.) (e.g., Villemant et al., 1993). The Srisotope data of Vesuvius magmas have a large range of values between 0.7069 and 0.7081 (e.g., Cortini and Hermes, 1981; Civetta et al., 1991; Civetta and Santacroce, 1992; Caprarelli et al., 1993; Santacroce et al., 1993; Cioni et al., 1995; Ayuso et al., 1998; Somma et al., 2001).

The role of evolutionary processes and the nature of source(s) in magma composition is debated: compositional variability of the erupted magma has been attributed to heterogeneous enriched mantle sources, to differentiation and magma mixing (e.g., Vollmer, 1976; Civetta et al., 1991; Civetta and Santacroce, 1992; Santacroce et al., 1993; Cioni et al., 1995; Ayuso et al., 1998; Peccerillo, 2001; Somma et al., 2001; Piochi et al., 2004) or to crustal contamination (e.g., Rittman, 1933; Savelli, 1967, 1968; Turi and Taylor, 1976). Contamination of magmas by assimilation of carbonate material has been also suggested for the genesis of $\mathrm{Ca}-\mathrm{Mg}$-silicate rich ejecta (skarns) on the basis of mineral chemistry, fluid inclusion and isotope data (e.g., Savelli, 1968; Fulignati et al., 1995, 1998; Gilg et al., 1999; 2001; Del Moro et al., 2001).

\section{Geochemistry and isotope geochemistry}

Volcanic products of Somma-Vesuvius have a potassic signature with different degrees of silica undersaturation. The most mafic rocks $\left(\mathrm{SiO}_{2}\right.$ less than $50 \mathrm{wt} \%$ ) have been produced during the last 300 years of volcanic activity. They commonly have low $\mathrm{Mg}$ numbers $(100 \times \mathrm{Mg} /$ $/ \mathrm{Mg}+\mathrm{Fe}=40-20$ ), and low Ni (less than 80 ppm) and $\mathrm{Cr}$ (less than $300 \mathrm{ppm}$ ) abundances indicating the non primary nature of these mafic rocks. Furthermore whole-rock compositions of these rocks do not always coincide with liquid compositions due to phenocrysts accumulation or depletion (Belkin et al., 1993; Trigila et al., 1993; Villemant et al., 1993). In general, as the fractionation index $\left(\mathrm{CaO} / \mathrm{Al}_{2} \mathrm{O}_{3}\right)$ decreases,
$\mathrm{SiO}_{2}, \mathrm{Al}_{2} \mathrm{O}_{3}, \mathrm{~K}_{2} \mathrm{O}, \mathrm{Na}_{2} \mathrm{O}, \mathrm{Rb}, \mathrm{Th}, \mathrm{Zr}$ and REE (except $\mathrm{Eu}$ ) contents increase, while $\mathrm{FeO}$ and $\mathrm{CaO}, \mathrm{Co}, \mathrm{Cr}, \mathrm{Ni}, \mathrm{Sc}$ and $\mathrm{V}$ contents decrease; $\mathrm{TiO}_{2}$ and $\mathrm{P}_{2} \mathrm{O}_{5}$ contents are roughly constant up to $\mathrm{CaO} / \mathrm{Al}_{2} \mathrm{O}_{3}$ of 0.5 , then decrease; $\mathrm{Sr}$ and $\mathrm{Ba}$ contents slightly increase up to $\mathrm{CaO} / \mathrm{Al}_{2} \mathrm{O}_{3}$ of 0.5 , then decrease (fig. 2). The strong enrichment in $\mathrm{K}$ and $\mathrm{Sr}$ abundances in the 472 A.D. products could be related to their high porphiricity (e.g., Rosi and Santacroce, 1983) that generates the nearly vertical trend such as that in fig. 2 and that could be the reason of their ultrapotassic character. These rocks are in fact constituted at $50 \%$ in volume of mineral phases (preferentially leucite crystals and subordinately clinopyroxene) in contrast to other Vesuvian plinian and sub-plinian rocks that are generally phenocryst poor. Chondrite-normalized REE patterns are generally light REE enriched, Eu anomaly is present in the most evolved rocks and increases according to the degree of fractionation (fig. 3a). Generally the described major and trace element variations range according to fractionation index indicating an origin for most of the evolved rocks by fractional crystallisation in magma reservoirs of the mineral phases observed on the liquidus. Constrains on pressure and temperature (P-T) conditions of these reservoirs come from melts and fluid inclusions trapped in phenocrysts which grow in magma chambers. FT-IR analyses on inclusions in phenocrysts (e.g., Belkin et al., 1985, 1998; Cortini et al., 1985; Belkin and De Vivo, 1993; Cioni et al., 1998; Marianelli et al., 1999; Cioni, 2000) indicate two different crystallization depths localized at $4 \mathrm{~km}$ and $>11 \mathrm{~km}$, and temperatures around $850-900^{\circ} \mathrm{C}$ and $1200^{\circ} \mathrm{C}$, respectively.

Moreover isotopic variations observed in Vesuvius rocks suggest processes other than crystal fractionation and accumulation during magma petrogenesis. In fact ${ }^{87} \mathrm{Sr} /{ }^{86} \mathrm{Sr}$ ratios ranges between 0.7069 and $0.7080 ;{ }^{143} \mathrm{Nd} /{ }^{144} \mathrm{Nd}$ ratio vary from 0.51261 to 0.51238 (fig. $3 b$ ); although the limited data, a variability is observed also for lead isotope ratios $\left({ }^{206} \mathrm{~Pb} /{ }^{204} \mathrm{~Pb}=18.95\right.$ $19.12 ;{ }^{207} \mathrm{~Pb} /{ }^{204} \mathrm{~Pb}=15.62-15.72 ;{ }^{208} \mathrm{~Pb} /{ }^{204} \mathrm{~Pb}=$ $=38.92-39.29$ ) (e.g., Civetta et al., 1991; Civetta and Santacroce, 1992; Caprarelli et al., 1993; Santacroce et al., 1993; Cioni et al., 1995; Ayuso et al., 1998; Somma et al., 2001). 


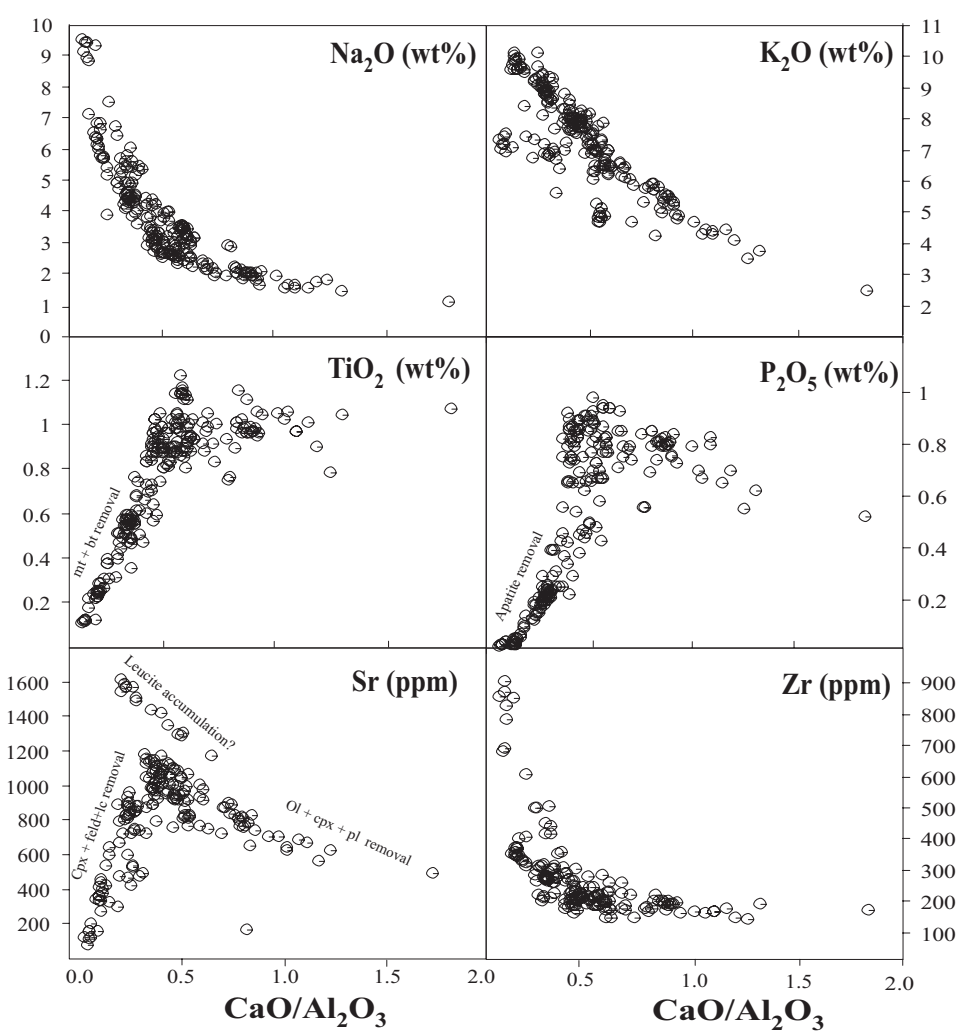

Fig. 2. Selected Harker diagrams. Symbols: open circles $=$ high explosive eruptions of the last $3350 \mathrm{kyrs}$, full circles $=$ moderate explosive/effusive eruptions erupted in the last 300 years. Data from Rosi and Santacroce (1983); Santacroce (1987); Civetta et al. (1991); Civetta and Santacroce (1992); Belkin et al. (1993); Santacroce et al. (1993); Trigila et al. (1993); Villemant et al. (1993); Cioni et al. (1995); Ayuso et al. (1998); Del Moro et al. (2001) and Somma et al. (2001).
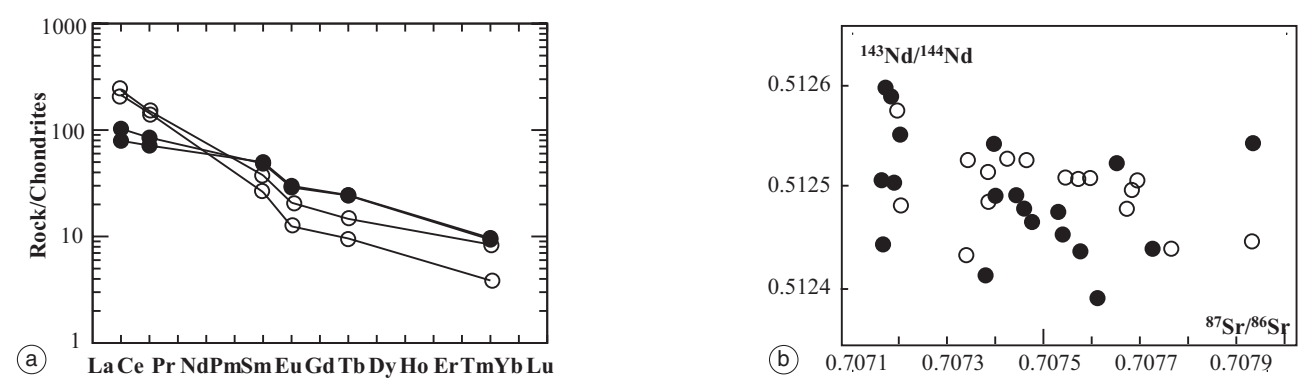

Fig. 3a-b. a) Rock/Chondrite spiderdiagram (Nakamura, 1974) for 1944 A.D. (closed circle) and 1631 A.D. (open circle) eruptions; b) Isotope versus Isotope diagrams. Sr-Nd isotope data from Cortini and Hermes (1981); Civetta et al. (1991); Civetta and Santacroce (1992); Santacroce et al. (1993); Caprarelli et al. (1993); Cioni et al. (1995); Ayuso et al. (1998); Del Moro et al. (2001) and Somma et al. (2001). Symbols as in fig. 2. 


\section{Interpretation of petrochemical data and modelling of crustal evolutionary processes}

Figure 4 shows a relationship from the Srisotopic ratios of minerals from rocks representative of different eruptions and the crystal-

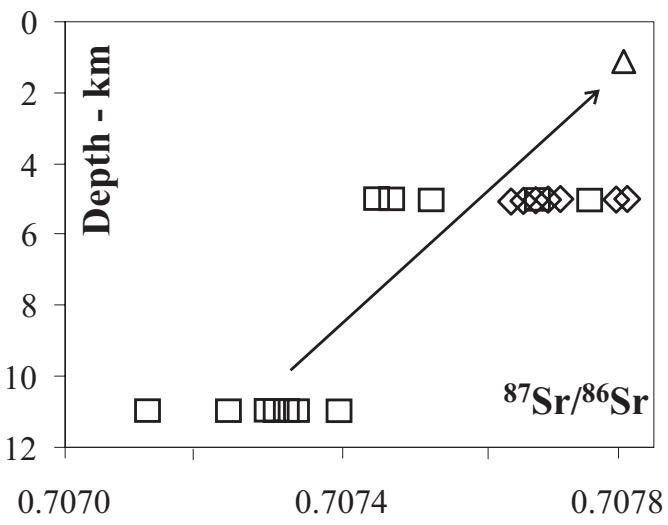

Fig. 4. Sr isotopic ratios of minerals versus equilibrium crystallization depth. Symbols: squares = diopside and salite, diamonds = feldspar, triangle = leucite. Isotopic data as in fig. 2, pressure data from Belkin et al. (1985; 1998), Cortini et al. (1985), Belkin and De Vivo (1993), Cioni et al. (1998), Marianelli et al. (1999), Cioni (2000). lization depths. In particular, diopsides derived from magma erupted during the 79 and 1944 A.D. eruptions have Sr-isotopic ratios lower than 0.7074 (Civetta et al., 1991; Civetta and Santacroce, 1992; Ayuso et al., 1998) and an equilibrium crystallization depth of 12$10 \mathrm{~km}$ (e.g., Belkin et al., 1985; Cortini et al., 1985; Belkin and De Vivo, 1993; Belkin et al., 1998; Marianelli et al., 1999). In addition, feldspars and salites from magma emitted during the 79 and 1906 A.D. eruptions have higher ${ }^{87} \mathrm{Sr} /{ }^{86} \mathrm{Sr}$ values $(0.7075-7)$ (Civetta and Santacroce, 1992; Santacroce et al., 1993) and an equilibrium crystallization depth of $4 \mathrm{~km}$ (Cioni et al., 1998; Cioni, 2000), moreover leucites have high Sr ratios (0.7077) and crystallization depth lower than $1 \mathrm{~km}$ (Cioni, 2000) (fig. 4). This suggests that the higher $\mathrm{Sr}$ isotopic ratios are acquired in a late stage of the crystallisation coincident sialic minerals growth at shallow depth. In contrast, the lower $\mathrm{Sr}$ isotopic ratios shown by diopsides and some whole-rocks could reflect that of the deeper reservoir, probably fed by more primitive magma.

The high Sr-isotope ratios acquired at shallow depth during crystallisation are consistent with the one inferred for crustal contamination processes, as also suggested by the systematic variations of Sr-isotopic ratios with differentiation index (fig. 5a,b). Evidence of open-system

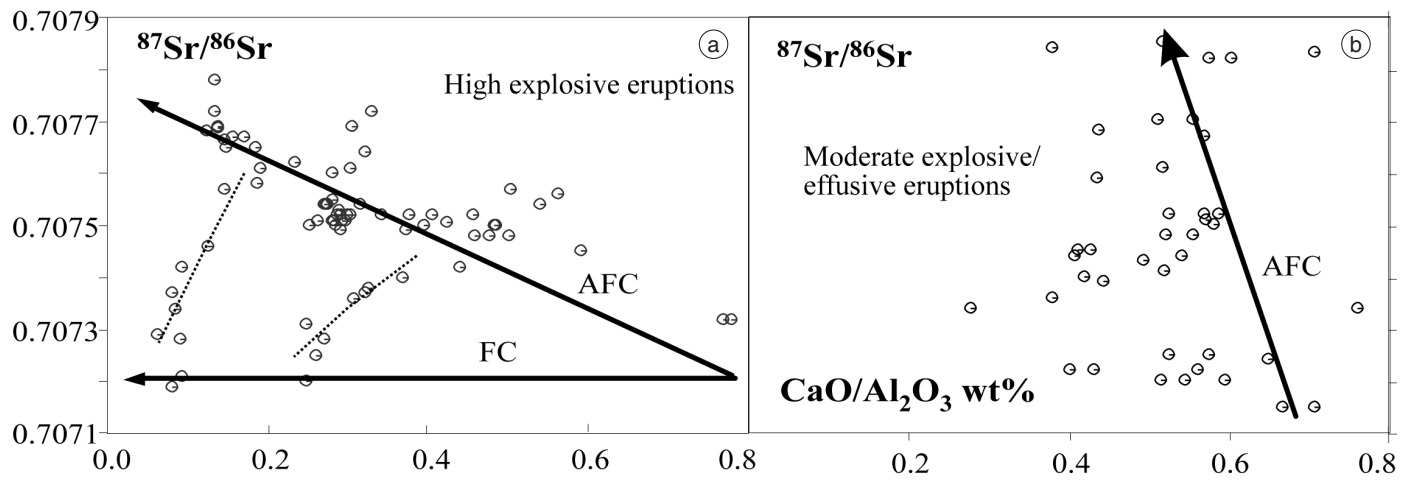

Fig. 5a,b. $\mathrm{CaO} / \mathrm{Al}_{2} \mathrm{O}_{3}$ versus ${ }^{87} \mathrm{Sr} /{ }^{86} \mathrm{Sr}$ ratios for high-explosive eruptions of the last $3550 \mathrm{kyr}$ (a) and moderate explosive/effusive eruptions of the last 1631 A.D. (b). Sr-isotope data as in fig. 2. Dashed lines $=$ mixing trends. 
magma processes, such as crustal contamination and/or fluids exchange processes, derives from O-isotope data (Turi and Taylor, 1976; Ayuso et al., 1998) and U-disequilibria (Black et al., 1998).

Plotting $\mathrm{CaO} / \mathrm{Al}_{2} \mathrm{O}_{3}$ wt $\%$ as fractionation index versus $\mathrm{Sr}$ isotopic ratios for a complete set of eruptions (fig. 5a-b) shows three main trends. Two trends are represented by the evolved rocks $\left(\mathrm{SiO}_{2}>50 \mathrm{wt} \%\right)$ generated during high explosive eruptions: the first shows at decreasing fractionation index against a quite constant $\mathrm{Sr}$ ratio around 0.7073 ; the second shows an overall increase in initial $\mathrm{Sr}$-isotopic ratios with fractionation from 0.7073 to 0.7077 . Isotopic disequilibrium between separated minerals and glass is a common feature for these evolved rocks. The third trend is represented by mafic rocks $\left(\mathrm{SiO}_{2}<50 \mathrm{wt} \%\right)$ produced during the last 300 years of moderate explosive/effusive activity and is characterized by an increase in radiogenic $\mathrm{Sr}$ from 0.7073 to 0.7078 at decreasing fractionation index. Isotopic equilibrium has been generally observed between separated minerals and glass. The scattering data observed in fig. 5a,b could be attributed to the existence of isotopic disequilibria, crystal accumulation, magma mixing (dashed lines in figure) different analytical procedures, etc.

Mesozoic carbonatic succession can be identified as the main source of magma contamination processes. This hypothesis can be inferred on the basis of geological, chemical and geophysical evidence: explosive eruptions which occurred at Somma-Vesuvius produced volcanic deposits containing carbonatic lithics clearly yielded from the wallrocks in which magma rises and fragments. Recently Fulignati et al. (1998), Del Moro et al. (2001) and Gilg et al. (2001) recognise that some volcanic magma erupted at Vesuvius shows chemico-isotopical evidence of interaction with carbonate country-rocks. Furthermore geophysical data identify the Mesozoic basement between 2 and not less than 8-11 km of depth (e.g., Imbò, 1949; Berrino et al., 1998; Zollo et al., 1996; 1998), where crystallization of sialic ${ }^{87} \mathrm{Sr}$-rich minerals occurred.

\subsection{Quantitative modelling of crustal contamination process}

In order to test the consistence of compositional variations of Somma-Vesuvius magmas with a crustal contamination model, we adopt the quantitative EC-AFC (Energy Conservation-Assimilation Fractional Crystallisation) approach that accounts for mass and energy conservation (Bohrson and Spera, 2001; Spera and Bohrson, 2001). Less-evolved samples with highest $\mathrm{MgO}$ content and lowest Sr-isotopic ratio were selected as magmatic end members (close to the parental magma compositions). The isotopic compositions of these samples are assumed to be unaffected by contamination relative to other samples with low $\mathrm{MgO}$ content. Carbonatic rocks were also used as end-members (representing the crustal contaminant). The obtained results (fig. $6 \mathrm{a}, \mathrm{b}$ and table I) show that the isotopic variations are consistent with a crystal fractionation process controlled by the contamination of carbonatic rocks. Since melting of limestone is an improbable event at the P$\mathrm{T}$ condition of Vesuvius magmas, the assimilation was likely a selective process consisting in the inter-exchange between magmas and fluids derived by thermal decomposition (decarbonisation process; Tracy and Frost, 1991) of the sedimentary wall-rocks. This process has been recently proposed for undersaturated volcanic products from the Albani Hills on the basis of petrological experiments (Freda et al., 2001).

In our approach, the values of thermo-chemical parameters (table I) were calculated from the chemistry of rocks and from data on melt inclusions (e.g., Belkin et al., 1985; Cortini et al., 1985; Belkin and De Vivo, 1993; Belkin et al., 1998; Cioni et al., 1998; Marianelli et al., 1999; Cioni, 2000). Calculations based on the above model indicate that the isotopic variations relative to the magmas feeding explosive eruptions (curve $\mathrm{b}$ in fig. 6a) are explained by the carbonatic contamination with a Ma* (mass of melted wall rock) $=0.10-0.25$ and $\mathrm{Mc}$ (mass of cumula- tes) $=0.60-0.75$. A fractionation mechanism involving sidewall crystallisation and liquid fractionation in the magma chamber (Chen and Turner, 1980; Mc Birney et al., 1985) can justify the high Mc values despite the crystal content 
observed in most pumice samples. Moreover, calculation based on the above model indicates that $\mathrm{Sr}$ isotopic variations observed in rocks younger than 300 years (curve $\mathrm{c}$ in fig. 6b) are consistent with $\mathrm{Ma}^{*}=0.2-0.4$ and $\mathrm{Mc}=0.6$ 0.7 . The high mass of cumulates is compatible with the higher crystal content - from 40 to $60 \%$
(Trigila and De Benedetti, 1993; Villemant et al., 1993) - observed in lavas. The higher Ma*/Mo ratio observed in mafic magma erupted in the last 300 years of activity (curve $\mathrm{c}$ in fig. 6b) is likely due to their higher $T$ and reduced volume of involved magma that favours the contamination processes.

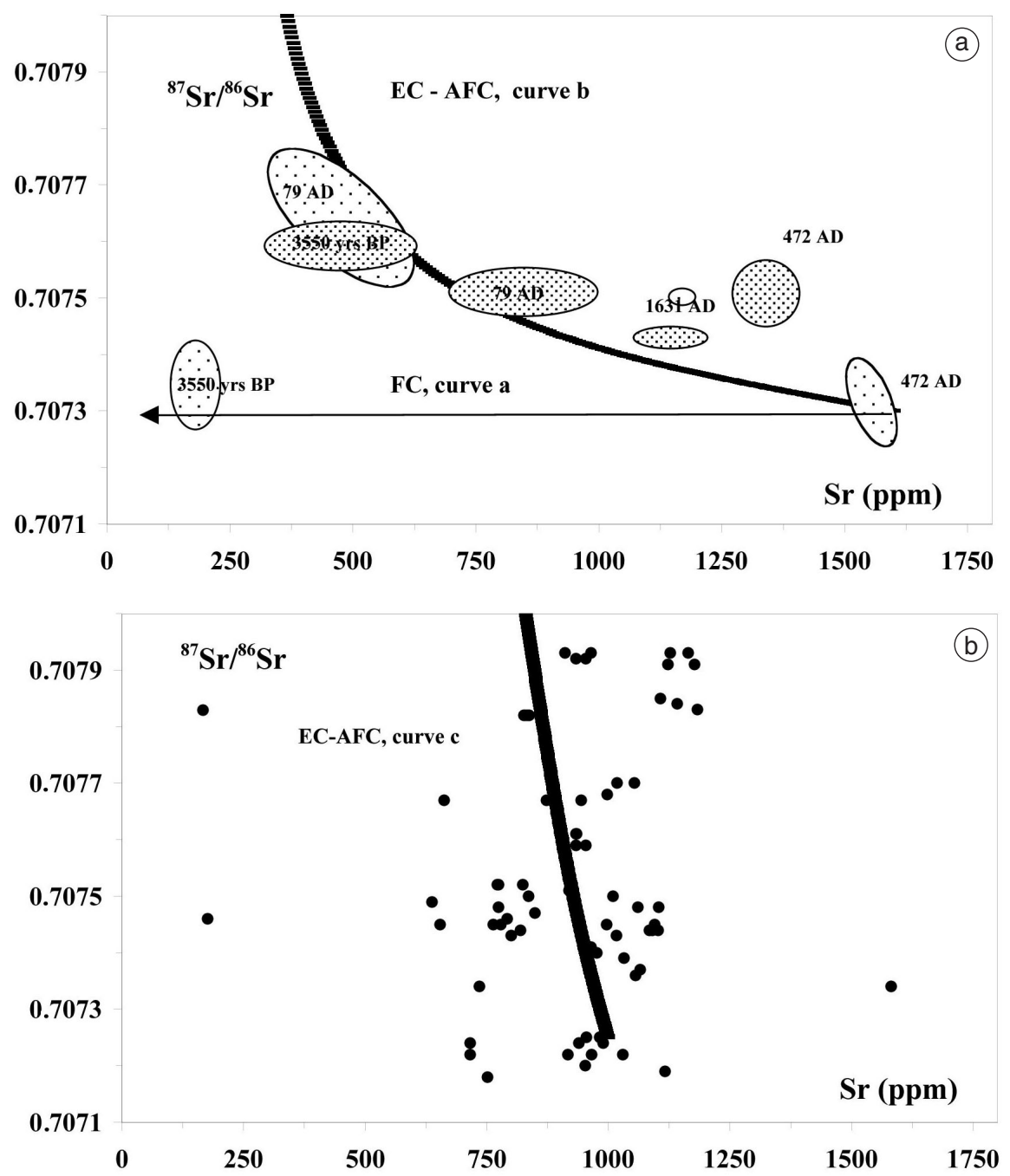

Fig. 6a,b. EC-AFC model following Spera and Bohrson (2001) and Bohrson and Spera (2001). Lines represent simulations made up using thermal and geochemical parameters listed in table I. Symbols and Sr-isotopic data as in fig. 2. In fig. 6a, light field indicate the white fallout layers, dark fields indicate the grey fallout layers. 
Table I. EC-AFC parameters, Somma-Vesuvius rocks.

\begin{tabular}{|c|c|c|c|c|c|c|}
\hline \multicolumn{3}{|c|}{$\begin{array}{l}\text { Thermal parameters } \\
\text { (curve b in figure } 6 a \text { ) }\end{array}$} & \multicolumn{4}{|c|}{ Compositional parameters } \\
\hline tlm & 1320 & ${ }^{\circ} \mathrm{C}$ & Element & $\mathrm{Sr}$ & $\mathrm{Nd}$ & $T h$ \\
\hline$t m_{0}$ & 1200 & ${ }^{\circ} \mathrm{C}$ & Magma: conc. & 1600 & 35 & 5 \\
\hline tla & 1000 & ${ }^{\circ} \mathrm{C}$ & bulk $D_{0}$ & 2.5 & 0.25 & 0.1 \\
\hline$t a_{0}$ & 750 & ${ }^{\circ} \mathrm{C}$ & Assimilant: conc. & 500 & 26 & 10.7 \\
\hline ts & 800 & ${ }^{\circ} \mathrm{C}$ & bulk $D_{0}$ & 3 & 0.25 & 0.1 \\
\hline cpm & 1484 & $\mathrm{~J} / \mathrm{kg} K$ & Isotope & ${ }^{87} \mathrm{Sr} /{ }^{86} \mathrm{Sr}$ & ${ }^{143} \mathrm{Nd} /{ }^{144} \mathrm{Nd}$ & \\
\hline cpa & 1370 & $\mathrm{~J} / \mathrm{kg} K$ & ratio magma & 0.7073 & 0.513 & \\
\hline hery & 396000 & $\mathrm{~J} / \mathrm{kg}$ & ratio assimilant & 0.71 & 0.5118 & \\
\hline hfus & 250000 & $\mathrm{~J} / \mathrm{kg}$ & & & & \\
\hline \multicolumn{7}{|c|}{ (curve $\mathrm{c}$ in figure $6 \mathrm{~b}$ ) } \\
\hline tlm & 1320 & ${ }^{\circ} \mathrm{C}$ & Element & $\mathrm{Sr}$ & $\mathrm{Nd}$ & $T h$ \\
\hline$t m_{0}$ & 1320 & ${ }^{\circ} \mathrm{C}$ & Magma: conc. & 1600 & 35 & 5 \\
\hline tla & 1000 & ${ }^{\circ} \mathrm{C}$ & bulk $D_{0}$ & 0.8 & 0.25 & 0.1 \\
\hline$t a_{0}$ & 750 & ${ }^{\circ} \mathrm{C}$ & Assimilant: conc. & 500 & 26 & 10.7 \\
\hline ts & 800 & ${ }^{\circ} \mathrm{C}$ & bulk $D_{0}$ & 1 & 0.25 & 0.1 \\
\hline cpm & 1484 & $\mathrm{~J} / \mathrm{kg} K$ & Isotope & ${ }^{87} \mathrm{Sr} /{ }^{86} \mathrm{Sr}$ & ${ }^{143} \mathrm{Nd} /{ }^{144} \mathrm{Nd}$ & \\
\hline cpa & 1370 & $\mathrm{~J} / \mathrm{kg} K$ & ratio magma & 0.7073 & 0.513 & \\
\hline hery & 396000 & $\mathrm{~J} / \mathrm{kg}$ & ratio assimilant & 0.71 & 0.5118 & \\
\hline hfus & 250000 & $\mathrm{~J} / \mathrm{kg}$ & & & & \\
\hline
\end{tabular}

Terminology from Spera and Bohrson (2001). $t \mathrm{tm}=$ liquidus of magma; $t m_{0}=$ initial temperature of magma; $t l a=$ liquidus of assimilant; $t a_{0}=$ initial temperature of assimilant; $t s=$ solidus temperature $; \mathrm{cm}=$ magma isobaric specific heat capacity; $c p a=$ assimilant isoba

\subsection{Evolution of magma plumbing system} in the last 300 years and its present state

The rocks erupted during the last 300 years of activity show a correlation between Sr-isotopic ratios and age (fig. 7). After the 1631 A.D. and until the 1737 A.D. eruption, the Sr-isotopic ratio remained constant thus indicating that magma was isotopically and geochemically similar to those erupted during the previous sub-plinian event. From 1737 A.D. to 1805 A.D. more radiogenic (0.708) magma was erupted. Then Sr-ratio decreases defining two distinct trends, as evidenced by Cortini and Hermes (1981), below 0.7074 during the 1906 A.D. eruption and below 0.7071 during the 1944 A.D. eruption. This was also evidenced by Somma et al. (2001) who reported time-dependent variations for Protohistoric, Ancient Historic and Medioeval lavas and tephra also for $\mathrm{Nd}$ and $\mathrm{Pb}$ isotopic ratios that 


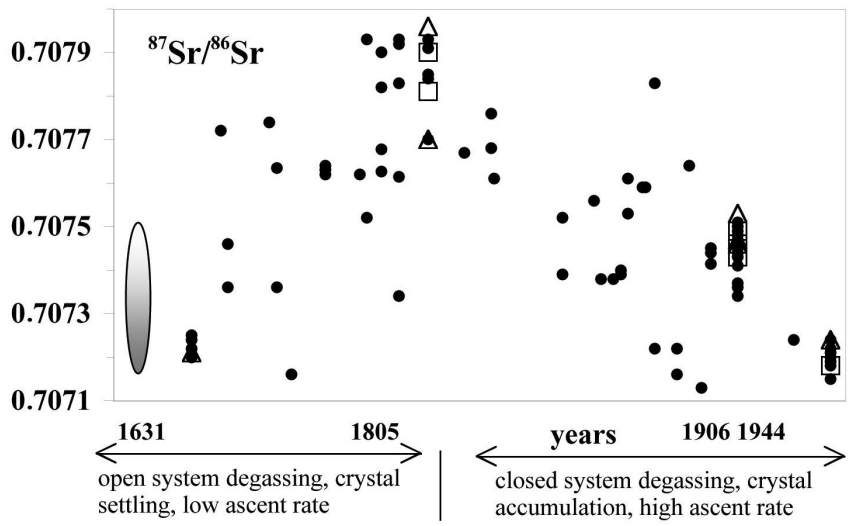

Fig. 7. Isotopic variations through time after the 1631 A.D. eruption. Symbols: open circles $=$ high explosive eruptions of the last 3550 years; full circles $=$ moderate explosive/effusive eruptions of the last 300 years; squares $=$ diopside; triangles = leucite. Field defines the compositional range of the 1631 A.D. volcanic products. Data as in fig. 2.

show an opposite behaviour with respect to that of ${ }^{87} \mathrm{Sr} /{ }^{86} \mathrm{Sr}$ ratios. Consistently with the above interpretation of Sr-isotope data, a residual shallower magma chamber was still active beneath the volcano between the 1631 A.D. and 1737 A.D. eruptions. The complete emptying of such a chamber allows mafic magma to ascent directly from the deep reservoir. The increasing isotopic ratios observed in rocks erupted between 1737 and 1805 A.D. likely derives from fractionation and crustal contamination processes at shallow depth in the conduit, consistently with the presence of high Sr-isotope ratio leucite (0.7077), crystallized at depth less than $1 \mathrm{~km}$ (Cioni, 2000). A progressive vanishing of crustal contamination processes occurred between 1805 A.D. and the last 1944 A.D. eruption, as indicated by the continuous decreasing of Sr ratios of erupted magmas. This vanishing possibly derives from cooling-induced crystal mush growth along conduit walls or, alternatively, from the rise in the magma ascent rate from the deep reservoir, both reducing magma/rocks exchange. Although the two hypotheses are both likely, the latter possibility is consistent with a general increase in eruption explosivity (e.g., Arrighi et al., 2001 and references therein) and the emission of poorly crystalline magma (e.g., Villemant et al., 1993) between 1805 and 1944 A.D., both characteristics of a degassing in near closed-system conditions (fig. 7).

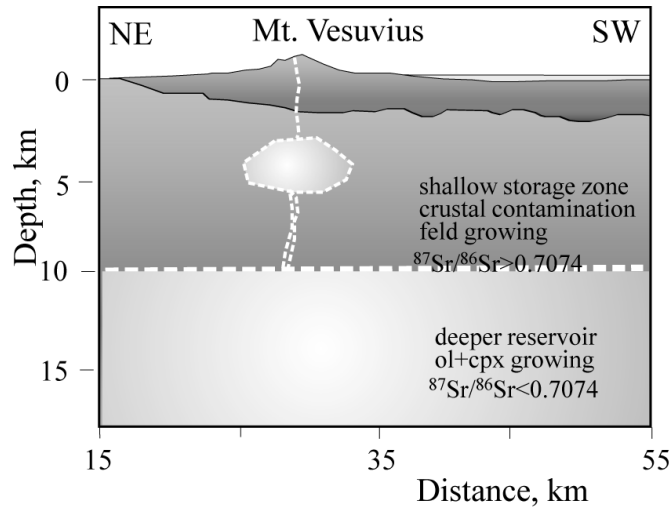

Fig. 8. Cartoon showing the supply system for Vesuvius reconstructed on the basis of the geochemical and Sr-isotopical modeling.

\section{Discussion and conclusions}

The relationship between the depth of magma crystallization and Sr-isotopic ratios, interpreted and quantitatively modelled as deriving from crustal contamination processes, indicates that the condition and timing of magma storage in the crust is a major controlling factor of the eruptive activity at Somma-Vesuvius. Less radiogenic $(0.70730)$ mafic crystals have 
equilibrium crystallization depth exceding 10 $\mathrm{km}$, while more radiogenic (0.7075-0.7077) sialic minerals have shallower equilibrium crystallization depth of about $5 \mathrm{~km}$. This suggests that the magma acquired higher $\mathrm{Sr}$-ratios by a process which occurred subsequently to its genesis, when sialic minerals crystallized at shallow depth, in the chamber or in the conduit. Magma storage at very shallow depth (likely in the upper conduit) being irrelevant, evidence of high Sr-isotope values of leucite at such depths (Cioni, 2000) implies that the contamination processes may occur even in a relatively short time.

The change in Sr-isotopic ratios through the last $300 \mathrm{yr}$ suggests that after the 1631 A.D. sub-plinian eruption and until the last 1944 A.D. eruption no significant shallower reservoir developed in the upper crust (fig. 8). This shallower reservoir probably grew during the long period of quiescence preceding the sub-plinian and plinian eruptions, by the periodical recharge of less contaminated magma rising from deeper storage zones (fig. 8). This shallow reservoir was partially or completely emptied during major explosive events. This magmatological evidence is strongly supported by the results of seismic tomography (e.g., Zollo et al., 1996; De Natale et al., 2001) which does not reveal seismic evidence of magma storage down to a depth of about 10 $\mathrm{km}$. In contrast, the recurrence of the lower isotopic imprints in the products of most of the Somma-Vesuvius eruptions suggests that the deep reservoir can be considered a long-lived reservoir acting throughout the volcanic history and furnishing at least $300 \mathrm{~km}^{3}$ (Santacroce and Civetta, 1992) of magma. Consistently with results of the recent seismic tomography (Zollo et al., 1996, 1998; De Natale et al., $2001)$, a large $\left(400 \mathrm{~km}^{2}\right.$ wide) reservoir, located at a depth between 8 and $25 \mathrm{~km}$ is still present beneath the volcano.

\section{Acknowledgements}

Authors are grateful to Chris Kilburn for suggestions that strongly improved the manuscript.

\section{REFERENCES}

ANDRONICO, D. and R. CIONI (2002): Contrasting styles of Mount Vesuvius activity in the period between the Avellino and Pompeii Plinian eruptions, and some implications for assessment of future hazards, Bull. Volcanol., 64, 372-391.

Arrighi, S., C. Principe and M. Rosi (2001): Violent strombolian and subplinian eruptions at Vesuvius during post-1631 activity, Bull. Volcanol., 63, 126-150.

Ayuso, R.A., B. De Vivo, G. Rolandi, R.R. SEal II and A. PAONE (1998): Geochemical and isotopic (Nd-Pb-Sr-O) variations bearing on the genesis of volcanic rocks from Vesuvius, Italy, J. Volcanol. Geotherm. Res., 82, 53-78.

Beccaluva, L., P. Di Girolamo and G. Serri (1991): Petrogenesis and tectonic setting of the Roman Volcanic province, Italy, Lithos, 26, 191-221.

BELKIN, H.E. and B. DE VIVo (1993): Fluid inclusion studies of ejected nodules from plinian eruptions of Mt. Somma-Vesuvius, J. Volcanol. Geotherm. Res, 58, 98-100.

Belkin, H.E., B. De Vivo, E. Roedder and M. Cortini (1985): Fluid inclusion geobarometry from ejected Mt. Somma-Vesuvius nodules, Am. Mineral., 70, 288-303.

Belkin, H.E., C.R.J. Kilburn, B. De Vivo and R. Trigila (1993): Sampling and analytical chemistry of the recent Vesuvius activity (1631-1944), J. Volcanol. Geotherm. Res., 58, 273-290.

Belkin, H.E., B. De Vivo, K. Torok and J.D. Webster (1998): Pre-eruptive volatile content, melt-inclusion chemistry, and microthermometry of interplinian Vesuvius lavas (pre-A.D. 1631), J. Volcanol. Geotherm. Res., 82, 79-95.

Berrino, G., G. Corrado and U. Riccardi (1998): Sea gravity data in the Gulf of Naples, a contribution to delineating the structural pattern of the Vesuvius area, $J$. Volcanol. Geotherm. Res., 82, 139-150.

Black, S., R. Macdonald, B. De Vivo, C.R.J. Kilburn and G. Roland (1998): U-series disequilibria in young (A.D. 1944) Vesuvius rocks, preliminary implications for magma residence times and volatile addition, J. Volcanol. Geotherm. Res., 82, 97-111.

Bohrson, W. and F.J. SPERA (2001): Energy-Constrained Open-system Magmatic Processes II, Application of Energy-Constrained Assimilation Fractional-Crystallization (EC-AFC). Model to Magmatic Systems, $J$. Petrol., 42, 1019-1041.

Brocchini, D., C. Principe, D. Castradori, M.A. LaURENZI and L. GoRLA (2001): Quaternary evolution of the southern sector of the Campanian Plain and early Somma-Vesuvius activity, insights from the Trecase 1 well, Miner. Petrol., 73, 67-91.

Caprarelli, G., S. Togashi and B. De Vivo (1993): Preliminary $\mathrm{Sr}$ and $\mathrm{Nd}$ isotopic data for recent lavas from Vesuvius volcano, J. Volcanol. Geotherm. Res., 58, 377-381.

CHEN, C.F. and J.S. TuRner (1980): Crystallization in a double-diffusive system, J. Geophys. Res., 85, 2573-2593.

CiOnI, R. (2000): Volatile content and degassing processes in the A.D. 79 magma chamber at Vesuvius (Italy), Contrib. Mineral. Petrol., 140, 40-54.

Cioni, R., L. Civetta, P. Marianelli, N. Metrich, R. SanTACROCE and A. SBRANA (1995): Compositional layering and syn-eruptive mixing of a periodically refilled 
shallow magma chamber, the A.D. 79 plinian eruption of Vesuvius, J. Petrol., 36, 739-776.

Cioni, R., P. Marianelli and R. SAnTACroce (1998): Thermal and compositional evolution of the shallow magma chambers of Vesuvius, evidence from pyroxene phenocrysts and melt inclusions, J. Geophys. Res., 103 , 18, 277-18, 294.

Civetta, L. and R. SAntacroce (1992): Steady state magma supply in the last 3400 years of Vesuvius activity, Acta Vulcanol., 2, 147-159.

Civetta, L., R. Galati and R. Santacroce (1991): Magma mixing and convective compo-sitional layering within the Vesuvius magma chamber, Bull. Volcanol., 53, 287-300.

Cortini, M. and O.D. Hermes (1981): Sr isotopic evidence for a multi-source origin of the potassic magmas in the Neapolitan area (Southern Italy), Contrib. Mineral. Petrol., 77, 47-55.

Cortini, M., A. Lima and B. De Vivo (1985): Trapping temperatures of melt inclusions from ejected vesuvian mafic xenoliths, J. Volcanol. Geotherm. Res., 26, 167-172.

Del Moro, A., P. Fulignati, P. Marianelli and A. Sbrana (2001): Magma contamination by direct wall rock interaction, constraints from xenoliths from the walls of a carbonate-hosted magma chamber (Vesuvius 1944 eruption), J. Volcanol. Geotherm. Res., 112, 15-24.

De Natale, G., C. Troise, F. Pingue, P. De Gori and C. ChiarabBa (2001): Structure and dynamics of the Somma-Vesuvius volcanic complex, Miner. Petrol., 73, 5-22.

Freda, C., M. Gaeta, D.M. Palladino and R. Trigila (2001): The Villa Senni eruption (Albani Hill, central Italy). The role of $\mathrm{H}_{2} \mathrm{O}$ and $\mathrm{CO}_{2}$ on the magma chamber evolution and on the eruptive scenario, J. Volcanol. Geotherm. Res., 78, 103-120.

Fulignati, P., A. Gioncada and A. Sbrana (1995): The magma chamber related hydrothermal system of Vesuvius, first mineralogical and fluid inclusion data on hydrothermalized subvolcanic and lavic samples from phreatomagmatic eruptions, Per. Mineral., 64, 185-187.

Fulignati, P., P. Marianelli and A. Sbrana (1998): New insights on the thermometamorphic-metasomatic magma chamber shell of the 1944 eruption of Vesuvius, Acta Vulcanol., 10 (1), 47-54.

Gilg, H.A., A. Lima, R. Somma, R.A. Ayuso, H.E. Belkin and B. De Vivo (1999): A fluid inclusion and isotope study of calc-silicate ejecta from Mt Somma-Vesuvius: evidence for interaction of high-temperature hypersaline fluids with the sedimentary basement., Proceedings of ECROFI XV, Potsdam, Germany, (abstracts and program), Terra Nostra, 99 (6), 118-120.

Gilg, H.A., A. Lima, R. Somma, H.E. Belkin, B. De Vivo and R.A. AYUSo (2001): Isotope geochemistry and fluid inclusion study of skarns from Vesuvius, Mineral. Petrol., 73, 145-176.

IMBò, G. (1949): L'attività eruttiva vesuviana e relative osservazioni nel corso dell'intervallo intereruttivo 19061944 ed in particolare del parossismo del marzo 1944, Ann. Osserv. Ves., 5, 185-380, Napoli.

Marianelli, P., N. Métrich, R. Santacroce and A. Sbrana (1995): Mafic magma batches at Vesuvius: a glass inclusion approach to the modalities of feeding stratovolcanoes, Contrib. Mineral. Petrol., 120, 159-169.
Marianelli, P., N. MÉtrich and A. Sbrana (1999): Shallow and deep reservoirs involved in magma supply of the 1944 eruption of Vesuvius, Bull. Volcanol., 61, 48-63.

Mastrolorenzo, G., R. MunNo and G. Rolandi (1993): Vesuvius 1906: a case study of a paroxysmal eruption and its relation to eruption cycles, J. Volcanol. Geotherm. Res., 58, 217-237.

Mastrolorenzo, G., D.M. Palladino, G. Vecchio and J. TADDEUCCI (2002): The 472 A.D. Pollena eruption of Somma-Vesuvius (Italy) and its environmental impact at the end of the Roman Empire, J. Volcanol. Geotherm. Res., 113, 19-36.

McBirney, A.R., B.H. BAKER and R.H. NILSON (1985): Liquid fractionation. Part 1, basic principles and experimental simulations, J. Volcanol. Geotherm. Res., 24, 1-4.

NAKAmura, N. (1974): Determination of REE, Ba, Fe, Mg, $\mathrm{Na}$ and $\mathrm{K}$ in carbonaceous and ordinary chondrites, Geochim. Cosmochim. Acta, 38, 757-73.

PeCCERILlO, A. (2001): Geochemical similarities between the Vesuvius, Phlegraean Fields and stromboli Volcanoes: petrogenetic, geodynamic and volcanological implications, Mineral. Petrol., 73, 93-105.

Piochi, M., L. Pappalardo and G. De Astis (2004): Geochemical and isotopical variations within the Campanian Comagmatic Province: implications on magma source composition, Ann. Geophys., 47 (4), 1485-1499 (this volume).

RitTman, A. (1933): Die geologische bedingte Evolution und Differentiation des Somma-Vesuvius magmas, $Z$. Vulkanol., 15, 1-2.

Rolandi, G., S. Maraffi, P. Petrosino and L. LiRer (1993): The Ottaviano eruption of Somma-Vesuvius ( 8000 years BP): a magmatic alternating fall and flow-forming eruption, J. Volcanol. Geotherm. Res., 58, 43-65.

Rolandi, G., P. Petrosino and J. Mc Geehin (1998): The interplinian activity at Somma-Vesuvius in the last 3500 years, J. Volcanol. Geotherm. Res., 82, 19-52.

Rosi, M. and R. SANTACROCE (1983): The A.D. 472 «Pollena» eruption: volcanological and petrological data for this poorly-known, plinian-type event at Vesuvius, J. Volcanol. Geotherm. Res., 17, 249-271.

SANTACROCE, R. (1987): Somma-Vesuvius, CNR, Quaderni de la Ricerca Scientifica, pp. 251.

Santacroce, R., A. Bertagnini, L. Civetta, P. Landi and A. SBRANA (1993): Eruptive dynamics and petrogenetic processes in a very shallow magma reservoir: the 1906 eruption of Vesuvius, J. Petrol., 34, 383-425.

SAVELli, C. (1967): The problem of rock assimilation by Somma-Vesuvius magmas, I, Compositions of SommaVesuvius lavas, Contrib. Mineral. Petrol., 16, 328-353.

SAVELLI, C. (1968): The problem of rock assimilation by Somma-Vesuvius magmas, II, Compositions of sedimentary rocks and carbonate ejecta from Vesuvius area, Contrib. Mineral. Petrol., 18, 43-64.

SCANDONE, R., F. IANNONE and G. Mastrolorenzo (1986): Stima dei parametri dinamici dell'eruzione del 1944 del Vesuvio, Boll. GNV, 2, 487-512.

Somma, R., R.A. Ayuso, B. De Vivo and G. Roland (2001): Major, trace element and isotope geochemistry $(\mathrm{Sr}-\mathrm{Nd}-\mathrm{Pb})$ of interplinian magmas from $\mathrm{Mt}$. Somma-Vesuvius (Southern Italy), Mineral. Petrol., 73, 121-143. 
SPERA, F.J. and W.A. BoHRSON (2001): Energy-constrained open-system magmatic processes. I. General model and Energy-Constrained Assimilation and Fractional Crystallization (EC-AFC) Formulation, J. Petrol., 42 (5), 999-1018.

TraCY, C.S. and B.R. Frost (1991): Phase equilibria and thermobarometry of calcareous, ultramafic and mafic rocks, and iron formations, Mineral. Soc. Am. Rev. Mineral., 26, 207-290.

Trigila, R. and A. De Benedetti (1993): Petrogenesis of Vesuvius historical lavas constrained by Pearce element ratios analysis and experimental phase equilibria, J. Volcanol. Geotherm. Res., 58, 315-343.

TURI, B and H.P. TAYLOR (1976): Oxigen isotope studies of potassic volcanic rocks of the Roman Province, Central Italy, Contrib. Mineral. Petrol., 55, 1-31.

Vilardo, G., G. Ventura and M. Girolamo (1999): Factors controlling the seismicity of the Somma-Vesuvius volcanic complex, Volc. Seismol., 20, 219-238.
Villemant, B., R. Trigila and B. De Vivo (1993): Geochemistry of Vesuvius volcanics during 1631-1944 period, J. Volcanol. Geotherm. Res., 58, 291-313.

VolLmeR, R. (1976): Rb-Sr and U-Th-Pb systematics of the alkaline rocks from Italy, Geochim. Cosmochim. Acta, 40, 283-295,

Zollo, A., P. Gasparini, J. Virieux, H. Le Meur, G. De NAtale, G. Biella, E. Boschi, P. Capuano, R. De Franco, P. Dell'Aversana, R. De Matteis, I. Guerra, G. IanNACCONE, L. MirabILE and G. VILARDo (1996): Seismic evidence for a low-velocity zone in the upper crust beneath Mount Vesuvius, Science, 274, 592-594.

Zollo, A., P. Gasparini, J. Virieux, G. Biella, E. Boschi, P. Capuano, R. De Franco, P. Dell' Aversana, R. De Matteis, G. De Natale, G. Iannaccone, I. Guerra, H. Le Meur and L. Mirabile (1998): An image of Mt. Vesuvius obtained by 2D seismic tomography, J. Volcanol. Geotherm. Res., 82, 161-173. 
